\title{
Effect of anthropic activity on the Imperial Cormorants and Rock Shags colonies in the Beagle Channel, Tierra del Fuego
}

Efectos de la actividad antrópica sobre las colonias del Cormorán Imperial y Cormorán de las Rocas en el Canal Beagle, Tierra del Fuego

\author{
Natalia G. Rosciano ${ }^{1}$, Walter S. Svagelj ${ }^{2}$ and Andrea Raya Rey ${ }^{1}$ \\ ${ }^{1}$ Ecología y Conservación de Vida Silvestre, Centro Austral de Investigaciones Científicas, Consejo Nacional de Investigaciones \\ Científicas y Técnicas, Bernardo A. Houssay 200 (V9410CAB), Ushuaia, Tierra del Fuego, Argentina. natirosciano@yahoo.com; \\ natirosciano@cadic-conicet.gob.ar \\ ${ }^{2}$ Biología y Manejo de Recursos Acuáticos, Centro Nacional Patagónico, Consejo Nacional de Investigaciones Científicas y \\ Técnicas, Boulevard Brown 2915, Puerto Madryn (U9120ACF); Chubut, Argentina
}

\begin{abstract}
Resumen.- Las aves marinas son importantes componentes del ecosistema marino y para las economías locales a través del ecoturismo. Distintas fuentes de disturbio humano pueden afectar a estas aves, causando un decrecimiento en el éxito reproductivo o el tamaño poblacional. Las colonias de nidificación de Phalacrocorax atriceps y P. magellanicus constituyen un atractivo turístico importante para la ciudad de Ushuaia, donde el número de embarcaciones turísticas que las visitan ha incrementado en los últimos años. Nuestro objetivo fue evaluar si hay influencia de las actividades humanas en la distribución y abundancia de las colonias de cormoranes y de los individuos en el mar, en el Canal Beagle, Tierra del Fuego. Se definieron variables explicatorias de origen antrópico, como distancia al recorrido del catamarán, y ambientales, como sustrato adecuado para anidar y batimetría, y se relacionaron con datos de tamaño de las colonias y la distribución de alimentación de los cormoranes. La distribución de las colonias y de los individuos en el mar de $P$. atriceps y $P$. magellanicus en el Canal Beagle no fueron afectadas por las actividades turísticas. La abundancia de $P$. magellanicus en las colonias estuvo asociada con islas de gran superficie de acantilados rocosos disponibles para anidar. La distribución de $P$. atriceps en el mar estuvo relacionada con aguas poco profundas. Aunque no se observó impacto antropogénico en nuestro estudio, dado el aumento del tráfico de embarcaciones y del turismo, se sugieren estudios más específicos y de largo plazo que permitan precisar pautas de manejo del turismo sustentable.
\end{abstract}

Palabras clave: Canal Beagle, disturbio humano, Phalacrocorax atriceps, Phalacrocorax magellanicus, turismo

\begin{abstract}
Seabirds are important components of the marine ecosystem and provide an income for local economies through ecotourism. Human disturbance may affect colonial birds causing a decrease in reproductive success and population size. Breeding colonies of Phalacrocorax atriceps and P. magellanicus, are one of the major tourist attractions of Ushuaia city and the number of tourist vessels visiting colonies increased in recent years. We aim to evaluate if there is an influence of human activities on the distribution and abundance of Cormorants' and Shags' colonies and individuals at sea in the Beagle Channel, Tierra del Fuego. Explanatory variables from anthropic source, such as distance to the vessels route, and environmental variables, as adequate substrate type to nest and bathymetry, for each species were defined and related to the data recorded of the size of both species colonies and the feeding distribution. Allocation of colonies and distribution at sea of $P$. atriceps and $P$. magellanicus in the Beagle Channel were not affected by tourism activities. Abundance of $P$. magellanicus at the colonies was associated to islands with a large surface of rocky cliffs available for nesting. Distribution of $P$. atriceps at sea was related to shallow waters. Although no anthropogenic impact was noticed in our study, given the increase in boat traffic and tourism, more specific and long term studies are encouraged to provide the precise and sitespecific guidelines for a sustainable tourism management allowing seabird conservation.
\end{abstract}

Key words: Beagle Channel, human disturbance, Phalacrocorax atriceps, Phalacrocorax magellanicus, tourism

\section{INTRODUCTION}

Seabirds are important components of the marine ecosystem and provide an income for local economies through ecotourism (Yorio et al. 2001). The availability and quality of suitable nesting habitats are important factors determining seabird distribution, abundance and breeding success. Also, for most species, breeding habitat 
has to be located close to abundant food sources, provide adequate nesting substrate and offer protection against predators (Furness \& Monaghan 1987, García Borboroglu \& Yorio 2004, Yasué 2006). Biological and physical attributes of the environment determine the feeding areas of seabirds (Hyrenbach et al. 2002). Therefore, the at-sea distribution of marine birds is determined by oceanographic processes that occur at different temporal and spatial scales and is restricted by energetic issues particularly during the breeding period (Guinet et al. 2001, Hyrenbach et al. 2002).

Seabirds are vulnerable to human activities such as fisheries, pollution, guano exploitation, habitat modification, introduction of exotic species and tourism (Yorio et al. 1999, 2001). Human disturbance may have different effects on colonial birds, depending on its source and intensity, but in most cases the consequence is a decrease in reproductive success and the size of the population (Anderson \& Keith 1980, Götmark 1992, Burger \& Gochfeld 1994, Carney \& Sydeman 1999, Beale \& Monaghan 2004) or at least prevents their increment (Woehler et al. 1994). Stress may have a negative effect on breeding birds, causing nest desertion (Yorio et al. 2001). Yet, it has been shown that negative effects can be minimized or even disappear if birds habituate to disturbance (Yorio \& Boersma 1992, Nisbet 2000, Cevasco et al. 2001, Martínez-Abraín et al. 2008, Villanueva et al. 2012). Meanwhile there are many studies that demonstrate the negative effects of tourists walking near or within a colony (Burger \& Gochfeld 1998), little is known about the effects of vessels disturbance on breeding and feeding birds, understanding disturbance as a suspension of the foraging or searching for food activity or temporary abandonment of the nest (Martínez-Abraín et al. 2002, Velando \& Munilla 2011). The Beagle Channel is situated in the southern coast of the Isla Grande de Tierra del Fuego. Numerous seabirds nest along the Beagle Channel and many others use these confined waters to feed (Raya Rey \& Schiavini 2000). Imperial Cormorants Phalacrocorax atriceps (Turbott, 1990) and Rock Shags Phalacrocorax magellanicus (Gmelin, 1789) breeding colonies represent one of the most important tourist attractions in Ushuaia city, which is the main city located in the Argentinean side of the channel and the southernmost city in the South American Continent. Tourist vessels visit Cormorants and Shags colonies sometimes approaching to less than $10 \mathrm{~m}$ from the islands where the birds are nesting, without having an apparent negative effect (Schiavini \& Yorio 1995). The number of tourist vessels has increased from 6 with a capacity of around 200 tourists in 1997 to 25 vessels with a capacity of more than 2000 tourists in 2007 (Secretaría de Turismo, Municipalidad de Ushuaia 2012르).

Imperial Cormorants and Rock Shags are distributed along the southern tip of South America (Nelson 2005); in particular in Argentina both species inhabit in Patagonia (Frere et al. 2005). The Beagle Channel holds colonies of both species (Schiavini \& Yorio 1995). Rock Shag colonies are located on rocky cliffs and steep slopes on islands or mainland usually in small groups of variable size (Schiavini \& Yorio 1995, Frere et al. 2005). In contrast, Imperial Cormorants nest on rocky substrate or plain areas without vegetation, generally in large groups (Punta et al. 2003a, Frere et al. 2005). Shallow waters, often associated to giant kelp beds (Macrocystis pyrifera), are the preferred feeding habitat for Rock Shags (Raya Rey \& Schiavini 2000), where they prey on benthic fish and/ or marine invertebrate such as crustaceans or cephalopods (Frere et al. 2005). Imperial Cormorants feed in both shallow and deep waters with higher occurrence in shallow waters along the channel (Raya Rey \& Schiavini 2000), but without an association with giant kelp beds. They prey mostly on pelagic and demersal fish and to a lesser extent on cephalopods and crustaceans (Frere et al. 2005).

Although habitat and feeding requirements were previously described for these 2 species (e.g., Punta et al. $2003 \mathrm{a}, \mathrm{b})$, there is a lack of information on the effects of human visitation on seabird colonies and animals foraging, in general for Argentina (Yorio \& Boersma 1992, Yorio \& Quintana 1996, Villanueva et al. 2012), and in particular along the Beagle Channel.

We aimed to assess if there is a human factor in the form of tourist visitation to colonies and closeness of the colonies to main cities influencing the distribution and abundance of both Imperial Cormorant and Rock Shag colonies and individuals foraging or in search of food at sea in the Beagle Channel. This was carried out with regards to selected environmental factors that are known to be important for the settlement of the colonies and the distribution at sea already studied, such as attributes of the field that provide suitable sites to nest and adequate patches to find preys at sea. We tested the hypothesis

${ }^{1}$ Secretaría de Turismo, Municipalidad de Ushuaia. 2012. Informe estadístico 1992-2011. Tierra del Fuego Prensa de Gobierno, Ushuaia, Argentina. 
that the size and/or location of the colonies are influenced by human disturbance as well as the abundance or presence of birds at sea, associated to food search, considering that animals perceive human disturbance in a similar way to predation risk (Walther 1969). In this scenario we expect to find larger colonies of both species as well as more individuals foraging at sea farthest from the focus of disturbance evaluated.

\section{Materials ANd Methods}

\section{STUDY AREA}

The Beagle Channel runs in an east-west direction along the southern coast of the Isla Grande de Tierra del Fuego at about $55^{\circ} \mathrm{S}$. The study area extended from the western limit of the Argentine sector of the Beagle Channel near Roca Peron to the waters around Becasses Island in the Eastern limit (Fig. 1 and 2). There are 32 islands and islets on the Argentinean sector of the Beagle Channel, where several species of seabirds nest.

Three cities are located along the Beagle Channel: Ushuaia, Puerto Almanza (both located in Tierra del Fuego, Argentina) and Puerto Williams (Chile). Ushuaia city is considered the most important given its population (70.000 inhabitants) and also because there has been a considerable increase of tourism, rising to 221.286 national and international tourists that visited the area during this research season (Secretaría de Turismo, Municipalidad de Ushuaia $2012^{1}$ ).

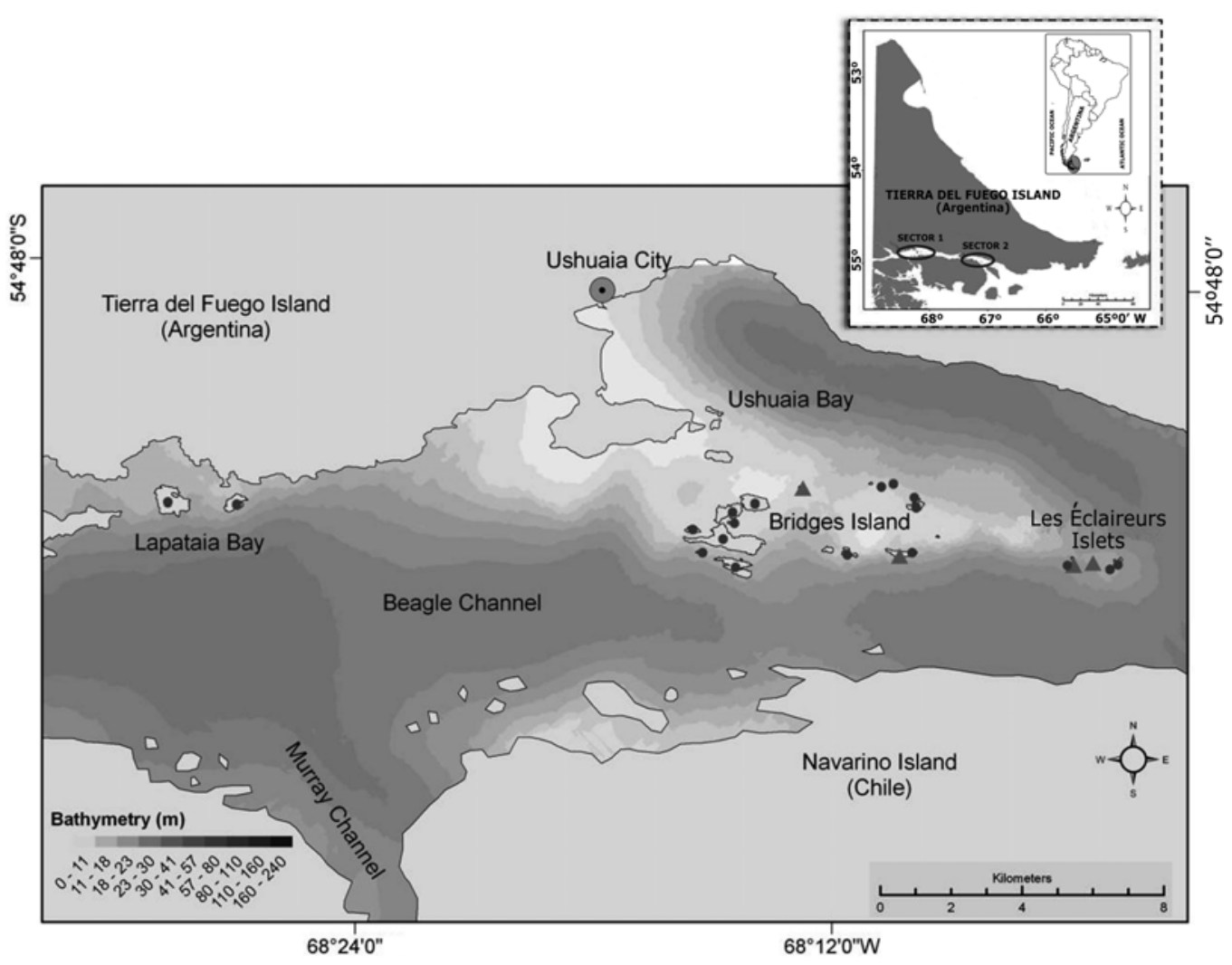

Figure 1. Tierra del Fuego Island, Argentina, the southernmost tip of Argentina; sectors 1 and 2 are indicated in the Beagle Channel and correspond to the western and eastern part of the study area, respectively. Below, Sector 1, western part, in detail Murray Channel and Bahia Lapataia area, Ushuaia Bay, Bridges Island and Les Éclaireurs Islets. The distribution of the birds' colonies is shown: circles correspond to Rock Shags (Phalacrocorax magellanicus) colonies and triangles to Imperial Cormorants (Phalacrocorax atriceps) colonies / Isla Grande de Tierra del Fuego, Argentina, la provincia más austral de la Argentina. Se indican los sectores 1 y 2 en el Canal Beagle, correspondientes a las zonas oeste y este del area de estudio, respectivamente. Debajo, sector 1 , parte oeste; en detalle se observa la zona de Canal Murray y Bahía Lapataia, Islas Bridges e Islotes Les Éclaireurs. Se observa la distribución de las colonias: los círculos corresponden al Cormorán de las Rocas (Phalacrocorax magellanicus) y los triángulos a las colonias de Cormorán Imperial (Phalacrocorax atriceps) 


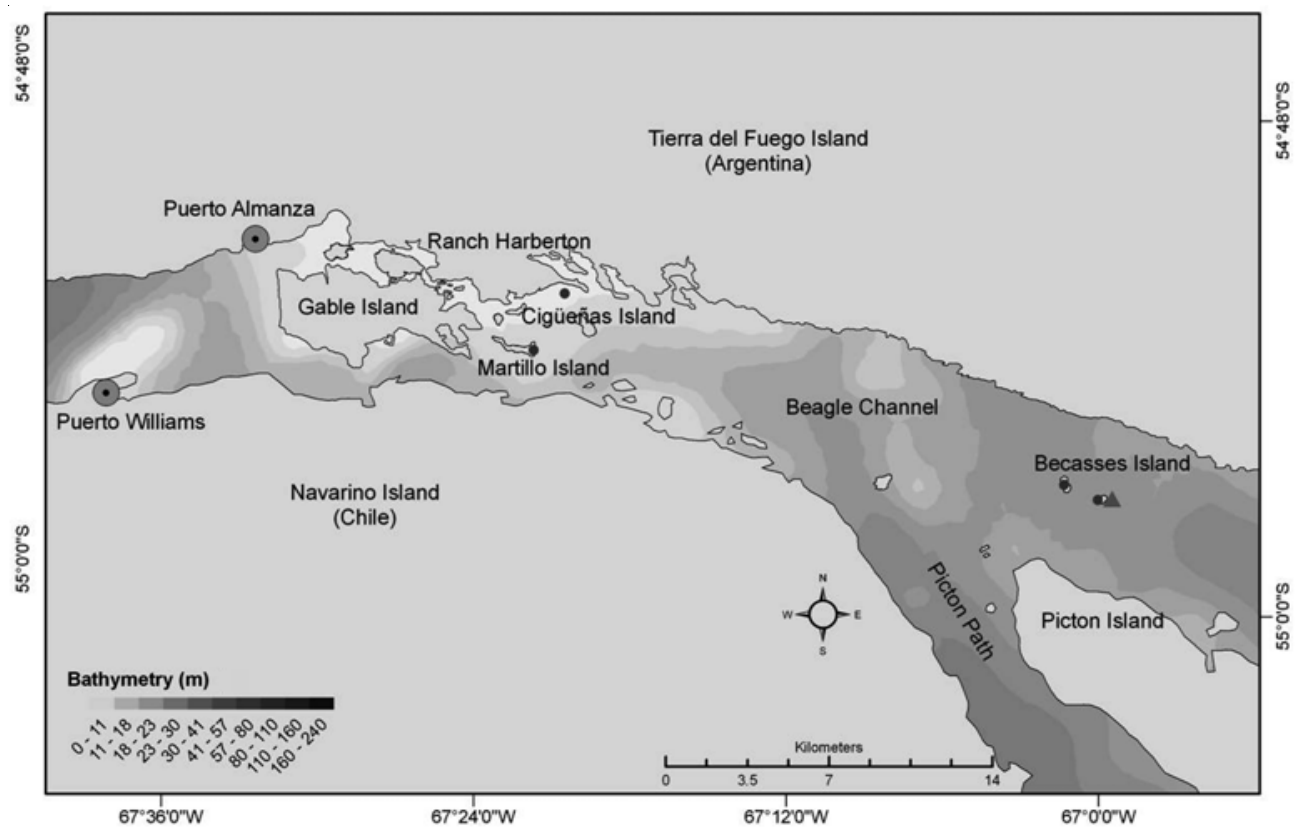

Figure2. The Beagle Channel, sector 2, eastern part; in detail Gable Island, Ranch Harberton, Becasses Island and Picton Path area. The distribution of the birds'colonies along the eastern side of the channel is shown: circles correspond to Rock Shags (Phalacrocorax magellanicus) colonies and triangles to Imperial Cormorants (Phalacrocorax atriceps) colonies / El Canal Beagle, sector 2, parte este; en detalle se observa la Isla Gable, Estancia Harberton, y la zona de Isla Becasses y Paso Picton. Se observa la distribución de las colonias: los círculos corresponden al Cormorán de las Rocas (Phalacrocorax magellanicus) y los triángulos a las colonias de Cormorán Imperial (Phalacrocorax atriceps)

\section{CENSUS OF NESTS ON THE IsLANDS}

To determine the distribution and abundance of Cormorant and Shag colonies along the channel, censuses were carried on during mid November 2008 at the time when most breeding pairs are settled and incubating. The counting unit was the active nest, understanding active as a nest occupied by a couple and containing eggs or chicks (Frere \& Gandini 1996).

The number of Imperial Cormorant couples nesting on the colonies was obtained from aerial photographs taken with a digital camera from a plane at $200 \mathrm{~m}$ height and at a speed of $222 \mathrm{~km} \mathrm{~h}^{-1}$. The sizes of the Rock Shag colonies were counted directly from an inflatable boat using binoculars. In both cases we considered a couple nesting when at least one of the parents was sitting on the nest, which could be discriminated from aerial photos as well. Those nests occupied by at least one of the members of the couple were considered as an active nest. All censuses were carried out by the same person in order to avoid miscounts produced by the observer. Even though the differences on the census techniques for the 2 species, in both cases all active nests or couples nesting were counted.
Both the abundance and distribution data of the Imperial Cormorants and the Rock Shags were added to a Geographical Information System (GIS, ArcGis 9.1, ESRI).

\section{Census of Birds at SEA}

To determine the occurrence of seabirds at sea, censuses were conducted on board tourist vessels and pilot ships, covering the study area. Five surveys were made: 2 from Murray Channel and Lapataia Bay to Ushuaia Bay on the $25^{\text {th }}$ and $28^{\text {th }}$ January 2009; 2 from Ushuaia Bay to Gable Island and Harberton Ranch on $25^{\text {th }}$ January and $28^{\text {th }}$ February 2009 and one from Harberton Ranch to Becasses Island and the Picton Path sector on the $6^{\text {th }}$ March 2009 (Fig. 1 and 2), totalizing $15 \mathrm{~h}$ and $7 \mathrm{~min}$ of observations on 4 different days.

We recorded all birds, Rock Shag and Imperial Cormorant, flying and on the water, sighted from the flying bridge, within a $90^{\circ}$ arc of radius $300 \mathrm{~m}$, extending from the bow to the side of the ship that offered the best visibility (Tasker 1984, Raya Rey et al. 2000). Data were registered on a palmtop with a Geopositioning System 
(GPS), using CyberTracker ${ }^{\circledR}$ software ${ }^{2}$. The survey was conducted all along the trip at a relatively constant speed (between 18.5-25.93 $\mathrm{km} \mathrm{h}^{-1}$ ) and we did not count when the ship stopped. All data were incorporated into a GIS and $a$ posteriori the trip was split into $5 \mathrm{~km}$-transects to obtain the number of birds of each species per transect. We computed a total of 31 transects for the tourist vessels surveys and 22 transect for the pilot ship, totalizing 53 transects, corresponding to $79.5 \mathrm{~km}^{2}$ covered in the 5 trips described before. It was assumed independence for the transects obtained. Each transect (and hence number of birds in each one) was associated to the explanatory variables selected (of 2 categories: anthropic and environmental), described in the next section.

\section{Anthropic and Environmental Data}

To evaluate the factors from anthropic source that may be related to the distribution of the Cormorants and Shags at sea and the colonies along the Beagle Channel, two variables were defined: distance to Ushuaia city $(\mathrm{km})$ and distance to tourist vessels route $(\mathrm{km})$. Also, some environmental variables were determined in view of the ecological relevance for each species given previous knowledge from their nesting habitat and feeding areas (see Table 1 for description). Hence we measured: availability of adequate substrate type to nest (\%, in particular for Imperial Cormorant), surface of rocky cliff available for nesting $\left(\mathrm{m}^{2}\right.$, in particular for Rock Shag), bathymetry (m) and distance to the nearest Rock Shags colony (km, in particular for Rock Shag).

Table 1. Description of the variables used to model of distribution in the Imperial Cormorants ( $P$. atriceps) and Rock Shags (P. magellanicus) at sea and the colonies along the Beagle Channel / Descripción de las variables usadas para el modelo de distribución del Cormorán Imperial ( $P$. atriceps) y Cormorán de las Rocas ( $P$. magellanicus) en el mar y las colonias a lo largo del Canal Beagle

\begin{tabular}{ll}
\hline Variable & Description \\
\hline
\end{tabular}

\section{Anthropic}

Distance to Ushuaia city (dush)

Distance to tourist vessels' route (dtour)

\section{Environmental}

Availability of adequate substrate type to nest (subs)

Surface of rocky cliff available for nesting (logslope)

Bathymetry (bat)

Distance to the nearest Rock Shags colony (dcen)
Distance $(\mathrm{km})$ from Ushuaia city to the islands and to the transects at sea. Ushuaia is considered the most influential city given its surface and the population size.

Distance $(\mathrm{km})$ from the islands placed on the Argentinean side of the Beagle Channel and the transects at sea to the regular tourist route. Tourist trips routes were recorded with a manual GPS. This variable was classify in two categories: a) $0-1 \mathrm{~km}$; and b) $>1 \mathrm{~km}$.
In particular for Imperial Cormorants: proportion of grass, herbs and shrubs + proportion rocks and bare ground, relative to the surface of the island. Data was taken from a Landsat 7 satellite image.

In particular for Rock Shags: using a digital elevation model (DEM, SPOT-4 satellite image $90 \mathrm{~m}$ resolution), the existing cliffs on each of the islands in the channel were identified and the length measured, then multiplied by the height of the island and/or certain cliff to obtain the effective surface available to nest. In those cases where the island was too small to be seen in a digital image, the size of the rocky cliff was measured in the field with a tape-measure. This variable was log transformed.

Depth data of the Beagle Channel was obtained from georreferenced and digitalized nautical charts maps. This data was interpolated using Krigging's method to obtain a map of the depths areas. To determine the bathymetry $(\mathrm{m})$ at the transects at sea, data from the interpolated areas was taken.

Minimum distance $(\mathrm{km})$ from the islands with Rock Shag's colonies to the transects was measured due to the species feeding behaviour, since they do not fly far away from the breeding colony to get food (Raya Rey \& Schiavini 2000).

${ }^{2}$ Cyber Tracker Conservation. 2012. <http://www.cybertracker.co.za> 
Variables values for each transect and colonies were obtained from GIS, using the Spatial Analyst extensions and the Hawth's tools (Beyer 2004³).

\section{Data ANALYsis}

\section{Distribution OF THE COLONIES ALONG THE CHANNEL}

Nests censuses were conducted in the 32 islands and islets located along the Argentinean side of the Beagle Channel, 22 on which Rock Shag occurred and only 5 with Imperial Cormorants nests.

The relationship between the abundance of Rock Shags and the explanatory variables measured, described as environmental and anthropic, was tested applying Generalized Linear Models (GLM) with a negative binomial distribution (Crawley 2007, Zuur et al. 2009). A negative binomial distribution of the data was assumed for Rock Shag's analysis because the Poisson model showed overdispersed data. The explanatory variables selected to model the abundance of the Rock Shag on the islands were: surface of rocky cliff available for nesting, distance to Ushuaia city and distance to tourist vessels route (see Table 1 for description of variables).

GLM with a binomial distribution of the data was performed to assess the relationship between the presence/absence of Imperial Cormorants on the islands and the explanatory variables measured, described as environmental and anthropic, (Crawley 2007, Zuur et al. 2009). Since there were only 5 islands of the 32 sampled with presence of the species, there were a few positive data and too many zeros to perform a count data analysis. The explanatory variables used to model the presence of Imperial Cormorants on the island were: availability of adequate substrate type to nest, distance to Ushuaia city and distance to tourist vessels route (see Table 1).

\section{DisTRIBUTION OF BIRDS AT SEA}

In order to analyze the relationship between the number of Imperial Cormorants counted per transect and the explanatory variables measured, described as environmental and anthropic, GLM with negative binomial distribution of the data was performed (Crawley 2007, Zuur et al. 2009), as the Poisson model showed overdispersed data. The following explanatory variables were considered in the model: bathymetry, distance to Ushuaia city and distance to tourist vessels' route.
Sample size was $n=22$ (transects) since only the records obtained from the censuses on board the pilot ships were used for this analysis and subsequently the distance to tourist vessels route was used as an explanatory variable.

To evaluate the relationship between the presence/ absence of Rock Shags per transect and the predictor variables (described as environmental and anthropic), GLM with a binomial distribution of the data was formulated, since there were not enough records to perform a count data analysis. The variables considered as explanatory of the abundance of Rock Shags at sea were: bathymetry, distance to the nearest Rock Shag's colony and distance to Ushuaia city. Rock Shags analysis was performed using both observations obtained from the census on board touristic vessel and pilot ships totalizing 53 transects.

\section{Model Selection}

Models with all possible combinations of explanatory variables for the presence/absence or abundance of Cormorants and Shags were considered. We selected 3 explanatory variables for each model due to the sample size. This resulted in 8 candidate models for each of the analysis performed. Following the information theoretic approach, Akaike's Information Criterion corrected for small sample size (AICc) was calculated in order to evaluate the models that best fitted the data (Burnham \& Anderson 2002). The difference between the lowest AICc value and AICc from all other models ( $\triangle \mathrm{AICc}$ ) was also calculated in order to rank the potential models (Burnham \& Anderson 2002). Also, the AICc weight of a model $\left(w_{i}\right)$ was calculated based on all candidate models according to Burnham \& Anderson (2002), representing the likelihood that a particular model is the best model, given the data and the candidate models considered. Complementarily, we evaluated the support for predictor variables summing $\mathrm{w}_{\mathrm{i}}$ across all models that contained the parameters being considered. Predictor variables with good support present high parameter-likelihood values $\left(\mathrm{w}_{\mathrm{i}}\right.$ near 1$)$. Parameter estimates were calculated using model-averaged parameter estimates based on $w_{i}$ for all candidate models and the unconditional variances were used to calculate standard errors. To supplement parameter- likelihood evidence of important effects, we also calculated $95 \%$ CI of parameter estimates (Burnham \& Anderson 2002).

${ }^{3}$ Beyer HL. 2004. Hawth's Analysis Tools for ArcGIS, <http://www.spatialecology.com/htools> 
Statistical analyses were performed using R software (MASS and MuMIn packages), version 2.13.1 (R Development Core team 20114). All values indicated are mean values \pm standard error (SE), unless otherwise noted.

\section{RESULTS}

We counted 7703 Imperial Cormorant active nests, distributed in 5 islands and 594 Rock Shag active nests in 22 islands during the study season (summer 2008-2009). Mixed colonies occurred only in $9.4 \%$ of the cases (3 islands).

\section{DisTRIBUTION OF THE COLONIES ALONG THE CHANNEL}

The model that best described the presence/absence of Imperial Cormorant colonies along the channel was the null model $\left(\mathrm{w}_{\mathrm{i}}=0.35\right.$, Table 2$)$. This indicates that none of the variables selected explained the presence of the birds nesting on the islands. Accordingly, the variables also showed small $\mathrm{w}_{\mathrm{i}}$ values and all the confidence intervals included zero (Table 3).

For the abundance of birds in the Rock Shags colonies, the models that best fitted the data set were the ones that included the variable surface of rocky cliff available for nesting $\left(\mathrm{w}_{\mathrm{i}}=0.48\right.$, Table 4$)$ and surface of rocky cliff available for nesting and distance to Ushuaia city $\left(\mathrm{w}_{\mathrm{i}}=\right.$ 0.27 , Table 4). The predictors weight showed that surface of rocky cliff available for nesting presented a $\mathrm{w}_{\mathrm{i}}>0.9$ ([0.46; 1.20], Table 5), indicating the importance of this variable to determine the abundance of Rock Shags on the colonies along the Beagle Channel. Rock Shags are more abundant on islands with larger surface of rocky cliff available for nesting ( $0.83 \pm 0.18$, Table 5$)$. The other 2 variables showed a minor weight value and they included the zero in their confidence intervals.

\begin{tabular}{|c|c|c|c|c|}
\hline \multicolumn{5}{|c|}{$\begin{array}{l}\text { models explaining the presence/absence of Imperial } \\
\text { Cormorant (Phalacrocorax atriceps) on the island in relation to } \\
\text { availability of substrate type to nest (subs), distance to Ushuaia } \\
\text { city (dush) and distance to the tourist vessels route (dtour). } K \\
\text { ( } \mathrm{n} \text { - of estimated parameters), AICc, } \Delta \text { AICc and } \mathbf{w}_{\mathrm{i}} \text { values for all } \\
\text { candidate models are presented / Resumen del resultado de } \\
\text { la selección de modelos para los modelos candidatos que } \\
\text { explican la presencia/ausencia del Cormorán Imperial } \\
\text { (Phalacrocorax atriceps) en las islas en relación con la } \\
\text { disponibilidad de sustrato apto para anidar (subs), distancia } \\
\text { a la ciudad de Ushuaia (dush) y distancia a la ruta de los } \\
\text { catamaranes (dtour). Se presentan los valores } K \text { ( } \mathrm{n} \text { o de } \\
\text { parámetros estimados), AICc, } \triangle \mathrm{AICC} \text { and } \mathrm{w}_{\mathrm{i}} \text { para todos los } \\
\text { modelos candidatos }\end{array}$} \\
\hline Candidate models & K & $\mathrm{AICc}$ & $\triangle \mathrm{AICc}$ & $\mathrm{w}_{\mathrm{i}}$ \\
\hline 1- Null & & 29.87 & 0.00 & 0.35 \\
\hline 2-dush & 2 & 31.29 & 1.42 & 0.17 \\
\hline 3-dtour & 2 & 31.47 & 1.60 & 0.16 \\
\hline 4- subs & 2 & 32.13 & 2.26 & 0.11 \\
\hline 5- subs + dush & 3 & 33.25 & 3.38 & 0.07 \\
\hline 6- subs + dtour & 3 & 33.36 & 3.49 & 0.06 \\
\hline 7- dush + dtour & 3 & 33.69 & 3.82 & 0.05 \\
\hline 8 - subs + dtour + dush & 4 & 35.66 & 5.79 & 0.02 \\
\hline
\end{tabular}

Table 3. Variables weight, estimates \pm SE and $95 \%$ confidence interval $(\mathrm{Cl})$ limits for each explanatory variable in the global model for the presence/absence of Imperial Cormorant (Phalacrocorax atriceps) on the islands / Peso de las variables, estimador \pm EE y límites de los intervalos de confianza (IC) del $95 \%$ para cada variable explicatoria del modelo global para la presencia/ausencia del Cormorán Imperial (Phalacrocorax atriceps) en las islas

\begin{tabular}{lccc}
\hline Explanatory variables & $\mathrm{w}_{\mathrm{i}}$ of the variable & variable estimate $\pm \mathrm{SE}$ & $\mathrm{CI}$ \\
\hline Intercept & - & $-1.82 \pm 0.61$ & {$[-3.06 ;-0.57]$} \\
Adequate substrate type to nest & 0.26 & $-0.05 \pm 0.12$ & {$[-0.29 ; 0.18]$} \\
Distance to tourist vessels route & 0.29 & $0.04 \pm 0.05$ & {$[-0.07 ; 0.14]$} \\
Distance to Ushuaia city & 0.31 & $0.02 \pm 0.02$ & {$[-0.03 ; 0.06]$} \\
\hline
\end{tabular}

\footnotetext{
${ }^{4}$ The R Foundation for Statistical Computing. Copyright (C) 2011. R version 2.13 .1
} 


\section{DisTRIBUTION OF BIRDS AT SEA}

The models that better explained the abundance of Imperial Cormorant per transect were: bathymetry $\left(\mathrm{w}_{\mathrm{i}}=\right.$ 0.55 , Table 6) and bathymetry and distance to the tourists vessels $\left(\mathrm{w}_{\mathrm{i}}=0.22\right.$, Table 6$)$. The average weight of the variable bathymetry was 1 and the confidence interval did not included the zero ([-0.03;-0.01], Table 7), and distance to Ushuaia city and distance to tourist vessels' route variables averaged a weight of 0.22 and 0.27 respectively, but both included zero in the confidence interval (Table 7). This result indicates the importance of the first variable for the distribution of the Imperial Cormorants at sea. Imperial Cormorants abundance per

Table 4. Summary of model-selection results for candidate models explaining the abundance of Rock Shags (Phalacrocorax magellanicus) on the island in relation to the surface of rocky cliff available for nesting (logslope), distance to Ushuaia city (dush) and distance to the tourist vessels route (dtour). $K$ ( $n$ - of estimated parameters), AICc, $\triangle A I C c$ and $w_{i}$ values for all candidate models are presented / Resumen del resultado de la selección de modelos para los modelos candidatos que explican la abundancia del Cormorán de las Rocas (Phalacrocorax magellanicus) en las islas en relación con la superficie de acantilados rocosos disponible para anidar (logslope), distancia a la ciudad de Ushuaia (dush) y distancia a la ruta de los catamaranes (dtour). Se presentan los valores $K$ ( $n$ o de parámetros estimados), $\mathrm{AICC}, \triangle \mathrm{AICC}$ and $\mathrm{w}_{\mathrm{i}}$ para todos los modelos candidatos

\begin{tabular}{lcccc}
\hline Explanatory variables & $\mathrm{K}$ & AICc & $\Delta \mathrm{AICc}$ & $\mathrm{w}_{\mathrm{i}}$ \\
\hline 1- logslope & 3 & 223.44 & 0.00 & 0.48 \\
2- dush+ logslope & 4 & 224.56 & 1.12 & 0.27 \\
3- dtour+logslope & 4 & 225.63 & 2.19 & 0.16 \\
4- dtour+dush+logslope & 5 & 227.18 & 3.74 & 0.07 \\
5- dush & 3 & 233.16 & 9.73 & 0.00 \\
6- Null & 2 & 234.20 & 10.76 & 0.00 \\
7- dtour+dush & 4 & 234.24 & 10.80 & 0.00 \\
8- dtour & 3 & 236.58 & 13.14 & 0.00 \\
\hline
\end{tabular}

transect at sea was inversely related to bathymetry: the deeper the sector of the channel, the less Cormorants would be found $(-0.021 \pm 0.005$, Table 7$)$.

For the distribution of the Rock Shags at sea, the models that better explained presence/absence of the birds per transect were: bathymetry and distance to the nearest Rock Shags colony $\left(\mathrm{w}_{\mathrm{i}}=0.33\right.$, Table 8$)$, the global model (that includes all the variables, $\mathrm{w}_{\mathrm{i}}=0.21$, Table 8), distance to the nearest Rock Shags colony and distance to Ushuaia city $\left(\mathrm{w}_{\mathrm{i}}=0.19\right.$, Table 8$)$, distance to the nearest Rock Shags colony $\left(\mathrm{w}_{\mathrm{i}}=0.12\right.$, Table 8$)$. Even though bathymetry and

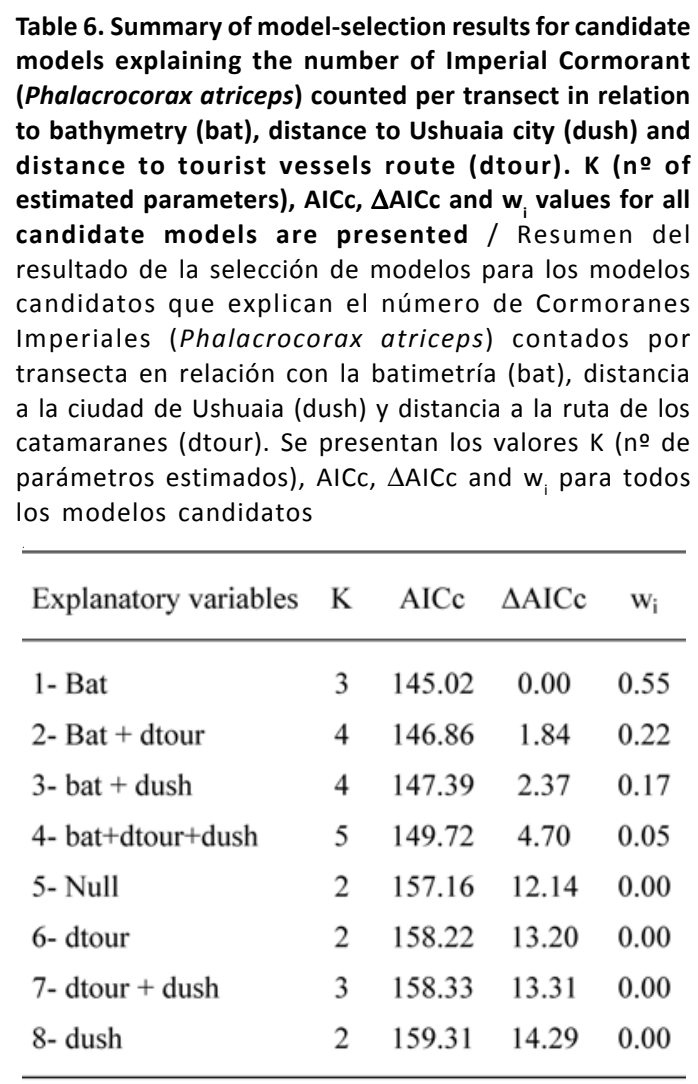

Table 6. Summary of model-selection results for candidate estimated parameters), AICc, $\triangle A I C c$ and $w_{\text {, values for all }}$ candidate models are presented / Resumen del resultado de la selección de modelos para los modelos transecta en a la ciudad de Ushuaia (dush) y distancia a la ruta de los catamaranes (dtour). Se presentan los valores K (no de parámetros estimados), AICc, $\triangle \mathrm{AICc}$ and $\mathrm{w}_{\mathrm{i}}$ para todos

Table 5. Variables weight, estimates \pm SE and $95 \%$ confidence interval $(\mathrm{CI})$ limits for each explanatory variable in the global model for the abundance of Rock Shag (Phalacrocorax magellanicus) on the islands / Peso de las variables, estimador \pm EE y límites de los intervalos de confianza (IC) del 95\% para cada variable explicatoria del modelo global para la abundancia del Cormorán de las Rocas (Phalacrocorax magellanicus) en las islas

\begin{tabular}{|c|c|c|c|}
\hline Explanatory variables & $\mathrm{w}_{\mathrm{i}}$ of the variable & variable estimate $\pm \mathrm{SE}$ & CI \\
\hline Surface of rocky cliff available for nesting & 0.99 & $0.83 \pm 0.18$ & {$[0.46 ; 1.20]$} \\
\hline Distance to tourist vessels route & 0.24 & $0.31 \pm 0.65$ & {$[-1.01 ; 1.64]$} \\
\hline
\end{tabular}


Table 7. Variables weight, estimates \pm SE and $95 \%$ confidence interval (CI) limits for each explanatory variable in the global model for the abundance of Imperial Cormorant (Phalacrocorax atriceps) per transect at the sea / Peso de las variables, estimador \pm EE y límites de los intervalos de confianza (IC) del $95 \%$ para cada variable explicatoria del modelo global para la abundancia de Cormorán Imperial (Phalacrocorax atriceps) por transecta en el mar

\begin{tabular}{lccc}
\hline Explanatory variables & $\mathrm{w}_{\mathrm{i}}$ of the variable & Variable estimate $\pm \mathrm{SE}$ & $\mathrm{CI}$ \\
\hline Intercept & - & $2.810 \pm 0.456$ & {$[1.88 ; 3.74]$} \\
Bathymetry & 1 & $-0.021 \pm 0.005$ & {$[-0.03 ;-0.01]$} \\
Distance to tourist vessels route & 0.27 & $-0.018 \pm 0.021$ & {$[-0.06 ; 0.02]$} \\
Distance to Ushuaia city & 0.22 & $-0.003 \pm 0.008$ & {$[-0.02 ; 0.01]$} \\
\hline
\end{tabular}

distance to the nearest Rock Shags colony showed a relative importance taking into account their weight in all the models they appeared $\left(\mathrm{w}_{\mathrm{i}}=0.66\right.$ and $\mathrm{w}_{\mathrm{i}}=0.85$, respectively, Table 9), both confidence intervals included zero. Consequently, none of the variables selected for this analysis explained the presence/absence of the Rock Shag at sea.

\section{Discussion}

Disturbance by human activities is known to affect seabird at several levels; influencing their distribution, behaviour, demography and/or population size (Gill 2007). However, little is known about the effect of vessel-based tourism on seabirds (Martínez-Abrain 2002, Rodgers et al. 2002, Ronconi \& Clair 2010, Velando \& Munilla 2011). In an attempt to evaluate a few particular sources of human influence on seabirds' colonies distribution along the Beagle Channel and birds at sea, we modelled both including 2 factors from anthropic source. Our results suggest that tourism activities did not influence either the location of colonies or the at-sea distribution of Rock Shags and Imperial Cormorants in the Beagle Channel.
Table 8. Summary of model-selection results for candidate models explaining the presence/absence of Rock Shags (Phalacrocorax magellanicus) per transect in relation to bathymetry (bat), distance to the nearest Rock Shag colony (dccn) and distance to Ushuaia city (dush). K ( $n$ - of estimated parameters), AICc, $\Delta$ AICc and $w_{i}$ values for all candidate models are presented / Resumen del resultado de la selección de modelos para los modelos candidatos que explican la presencia/ausencia del Cormorán de las Rocas (Phalacrocorax magellanicus) por transecta en relación con la batimetría (bat), distancia a la colonia de Cormorán de las Rocas más cercana (dccn) y distancia a la ciudad de Ushuaia (dush). Se presentan los valores $\mathrm{K}$ ( $\mathrm{n}$ o de parámetros estimados), AICc, $\triangle \mathrm{AICC}$ and $\mathrm{w}_{\mathrm{i}}$ para todos los modelos candidatos

\begin{tabular}{lcccc}
\hline Candidate models & $\mathrm{K}$ & AICc & $\Delta \mathrm{AICc}$ & $\mathrm{w}_{\mathrm{i}}$ \\
\hline 1- bat + dccn & 3 & 29.21 & 0.0 & 0.33 \\
2- bat + dccn + dush & 4 & 30.06 & 0.86 & 0.21 \\
3- dccn + dush & 3 & 30.33 & 1.12 & 0.19 \\
4- dccn & 2 & 31.16 & 1.95 & 0.12 \\
5- bat & 2 & 31.94 & 2.74 & 0.08 \\
6- bat + dush & 3 & 33.86 & 4.66 & 0.03 \\
7- Null & 1 & 35.20 & 5.99 & 0.02 \\
8- dush & 2 & 35.68 & 6.48 & 0.01 \\
\hline
\end{tabular}

Table 9. Variables weight, estimates \pm SE and $95 \%$ confidence interval $(\mathrm{Cl})$ limits for each explanatory variable in the global model for the presence/absence of Rock Shags (Phalacrocorax magellanicus) per transect at the sea / Peso de las variables, estimador \pm EE y límites de los intervalos de confianza (IC) del 95\% para cada variable explicatoria del modelo global para la presencia/ausencia del Cormorán de las Rocas (Phalacrocorax magellanicus) por transecta en el mar

\begin{tabular}{lccc}
\hline Explanatory variables & $\mathrm{w}_{\mathrm{i}}$ of the variable & variable estimate $\pm \mathrm{SE}$ & $\mathrm{CI}$ \\
\hline Intercept & - & $-0.11 \pm 1.46$ & {$[-2.97 ; 2.75]$} \\
Bathymetry & 0.66 & $-0.03 \pm 0.02$ & {$[-0.07 ; 0.01]$} \\
Distance to the nearest Rock Shag colony & 0.85 & $-0.41 \pm 0.25$ & {$[-0.90 ; 0.08]$} \\
Distance to Ushuaia city & 0.45 & $0.026 \pm 0.02$ & {$[-0.01 ; 0.07]$} \\
\hline
\end{tabular}


Since touristic activities began in the study area in 1992, there is scarce information reported on this matter. Ghys et al. (2008) described a growing colony of Papua Penguins (Pygocelis papua) in Martillo Island visited by tourist vessels, which showed no apparent effect of this activity by that time. Also, Rosciano (2011) reported that Imperial Cormorant and Rock Shag colonies in the Beagle Channel showed no significant increase or decrease of the population growth rate during the last 15 years, period in which tourism visiting seabird colonies has been developed.

Imperial Cormorants are known to select open rocky outcrops to nest along the Patagonia coast of Argentina (Punta et al. 2003a, Frere et al. 2005). In the Beagle Channel, Imperial Cormorants colonies were located both on open rocky outcrops and also in areas covered with grass. Nevertheless, none of the environmental characteristics measured explained the presence of the birds nesting on the islands. There are a low number of islands where this species breeds in the study area, what makes it difficult to get statistically valid conclusions. Meanwhile, steep slopes areas are known to determine Rock Shags distribution in north Patagonia (Punta et al. 2003a, Frere et al. 2005). In agreement we found that the abundance of this species was strongly associated to islands with a large surface of rocky cliffs available for nesting.

Although our results suggest there is no effect of the 2 variables from anthropic source studied, it is interesting to consider, for the long term monitoring, the dynamic of Cormorant and Shag colonies in the Beagle Channel. Martínez-Abraín et al. (2002) documented changes in the number of nesting couples of Falco eleonorae at different islands of the Columbretes archipelago. They found a decreased number of couples on an island subject to increasing presence of tourism and vice versa without changes in the overall number of couples, suggesting a rearrangement of couples nesting on the islands. As it was discussed above, the Imperial Cormorant and Rock Shag colonies in the Beagle Channel remained stable for the last 15 years, although changes were noted in the number of couples nesting on the different islands between years (Rosciano 2011). A rearrangement of the colonies of Cormorants and Shags on the Beagle Channel may be occurring in the study area as it was described for Falco eleonorae.

Previous studies have noticed that differences in spatial aggregation of tourists is likely to result in nests receiving different levels of disturbance, since the stress would vary when visitors are spread all around the colony or all aggregated (Beale 2007). Given the differences in the type of substrate used for nesting by Imperial Cormorants and Rock Shags in the study area, and considering the vessels approach to the colonies during the tourist visits, the intensity of disturbance may be perceived differently by the 2 species. For instance, the Rock Shag nests are all exposed at the same distance to disturbance since they are located on the cliffs of the island. In contrast, the Imperial Cormorants nests are situated on the flat part of the island, so the nests situated in the periphery of the colony would perceive a greater intensity of disturbance, which would dissipate as we move to the centre of the colony (Beale 2007). In this context, the movements observed between islands could be related to the differences in the stress Shags and Cormorants receive in those 2 different scenarios related to the substrate used to nest.

Our modelling of birds at sea revealed that Imperial Cormorants were related to shallow waters, but in the case of the Rock Shags the results were inconclusive, even though other studies have shown they are found close to the colonies, presumably associated to giant kelp beds (Raya Rey \& Schiavini 2000). Imperial Cormorants dive up to $40 \mathrm{~m}$ in the Beagle Channel (Raya Rey unpublished data), where the deepest waters reach around $250 \mathrm{~m}$ deep.

The low number of Rock Shags individuals encountered in the present study may be given by the fact that Rock Shags feed among giant kelp beds and the impossibility of the boats to manoeuvre in areas covered by macroalgae. Conversely, Imperial Cormorants are distributed in shallow waters all along the Beagle Channel as we found in the present study, but not associated with giant kelp (Raya Rey \& Schiavini 2000). Thus, the preference for shallow waters influence the species in a different manner, in this case we presume that Rock Shags would be less affected by any vessel activity than Imperial Cormorants. Boats, watercraft and outboard power vessels are known to affect seabirds feeding (Rodgers et al. 2002, Velando \& Munilla 2011) and so Imperial Cormorant in the Beagle Channel could be potentially more affected. Velando \& Munilla (2011) showed that European Shags (Phalacrocorax aristotelis) spend more time alerted than foraging when boat traffic increased in the areas where the birds aggregate to forage. Also flushing behaviour increases in response to distance approach and boat size and speed (Ronconi \& Claire 2002), which may exclude the birds from their preferred foraging 
sites or cause stress (Whittaker \& Knight 1998, FernándezJuricic \& Tellería 2000). Since marine birds are constrained to feed close to their colonies during the chick rearing period (Furness \& Monaghan 1987) boat traffic within those areas could prevent them from using optimal foraging areas (Rodgers et al. 2002, Velando \& Munilla 2011). Thus, conflicts between seabird and tourism are likely to increase if boat traffic intensifies (cruise ships, tourist vessels, sailing ships and inflatable boats) in those scenarios.

Although Schiavini \& Yorio (1995) informed the presence of Rock Shag and Imperial Cormorant colonies on the Chilean side of the Beagle Channel, there is no further information about those colonies. Given the importance of these studies and knowing that there is not such a thing as political limits for biodiversity, it would be important to include in future studies both sides of the channel, Argentinean and Chilean, in order to get the whole picture of the situation of these seabirds population and the dynamic of their colonies.

Marine protected areas have been proposed as an essential tool for seabird conservation (Yorio 2009) and also the design of buffer areas to protect the places where birds usually feed to minimize the disturbance (Rodgers 2002, Velando \& Munilla 2011). Additionally, it was suggested by Beale \& Monaghan (2004) to periodically reassess the viewpoints used by tourists and if necessary, for example move them farther from nests if increasing visitor numbers have negative influence on nesting birds. Although the Beagle Channel is not currently a Marine Protected Area, tourist guidelines had been set up through a local certification that regulates the tourism in the Beagle Channel, the Onashaga Distinctive. The Onashaga Commitment was signed in 2005 by $90 \%$ of the tourist companies that operate in the Beagle Channel in order to promote a sustainable tourism to protect the natural resources in the area and in 2011 turn to a local certification. In this scenario, further research on seabird population studies in relation with the tourist activity is important to provide precise and site-specific guidelines that integrate the certification for an optimal management of the activity and seabird conservation.

\section{ACKNOWLedgment}

This study was supported by Agencia Nacional de Promoción Científica y Técnológica, PICT 2006 Nº 2026, and Wildlife Conservation Society. We thank Nautilus S.A., Tolkeyen and Rumbo Sur for logistic support to conduct the censuses on board the pilot ships and tourist vessels, and Ricardo Saenz Samaniego for field assistance. We especially thank to anonymous reviewers that contribute to greatly improve the manuscript with their suggestions.

\section{LITERATURE CITED}

Anderson DW \& JO Keith. 1980. The human influence on seabird nesting success: conservation implications. Biological Conservation 18: 65-80.

Beale CM. 2007. Managing visitor access to seabird colonies: a spatial simulation and empirical observations. Ibis 149: 102-111.

Beale CM \& P Monaghan. 2004. Behavioral responses to human disturbance: a matter of choice? Animal Behavior 68: 1065-1069.

Burger J \& M Gochfeld. 1994. Predation and effects of humans on island-nesting seabirds. In: Nettleship DN, J Burger \& M Gochfeld (eds). Seabirds on Islands. Threats, case studies and action plans, pp. 39-67. Birdlife International, Birdlife Conservation Series 1, Cambridge.

Burger J \& M Gochfeld. 1998. Effects of ecotourists on bird behaviour at Loxahatchee National Wildlife Refuge, Florida. Environmental Conservation 25: 13-21.

Burnham KP \& DR Anderson. 2002. Model selection and multimodel inference: a practical information-theoretic approach, 488 pp. Springer-Verlag, New York.

Carney KM \& WJ Sydeman. 1999. A review of human disturbance effects on nesting colonial waterbirds. Waterbirds 22: 68-79.

Cevasco C, E Frere \& P Gandini. 2001. Intensidad de visitas como condicionante de la respuesta del Pingüino de Magallanes (Spheniscus magellanicus) al disturbio humano. Ornitología Neotropical 12: 75-81.

Crawley MJ. 2007. The R book, 942 pp. Wiley, West Sussex.

Fernández-Juricic E \& JL Tellería. 2000. Effects of human disturbance on spatial and temporal feeding patterns of Blackbird Turdus merula in urban parks in Madrid, Spain. Bird Study 47: 13-21.

Frere E \& P Gandini. 1996. Conceptos generales para la evaluación y monitoreo de poblaciones de aves marinas. Informe Técnico 8: 1-25. Plan de Manejo Integrado de la Zona Costera Patagónica, Fundación Patagónica Natural, Wildlife Conservation International. <http:// www.patagonianatural.org/attachments/247_IT08.pdf>

Frere E, F Quintana \& P Gandini. 2005. Cormoranes de la costa patagónica: estado poblacional, ecología y conservación. El Hornero 20: 35-52.

Furness RW \& P Monaghan. 1987. Seabird ecology, 164 pp. Chapman \& Hall, Methuen.

García Borboroglu P \& P Yorio. 2004. Habitat requirements and selection by kelp gulls (Larus dominicanus) in central and northern Patagonia, Argentina. The Auk 121: 243-252. 
Ghys MI, A Raya Rey \& A Schiavini. 2008. Population trend and breeding biology of Gentoo Penguin in Martillo Island, Tierra del Fuego, Argentina. Waterbirds 31: 625-631.

Gill JA. 2007. Approaches to measuring the effects of human disturbance on birds. Ibis 149: 9-14

Götmark F. 1992. The effects of investigator disturbance on nesting birds. Current Ornitology 9: 63-104.

Guinet C, L Dubroca, MA Lea, S Goldsworthy, Y Cherel, G Duhamel, F Bonadonna \& JP Donnay. 2001. Spatial distribution of foraging in female Antartic fur seals Arctocephalus gazelle in relation to oceanographic variables: a scale-dependent approach using geographic information systems. Marine Ecology Progress Series 219: 251-264.

Hyrenbach KD, P Fernández \& DJ Anderson. 2002. Oceanographic habitats of two sympatric North Pacific albatrosses during the breeding season. Marine Ecology Progress Series 233: 283-301.

Martínez-Abraín A, D Oro, V Ferrís \& R Belenguer. 2002. Is growing tourist activity affecting the distribution or number of breeding pairs in a small colony of the Eleonora's Falcon? Animal Biodiversity and Conservation 25: 47:51.

Martínez-Abraín A, D Oro, D Conesa \& J Jiménez. 2008. Compromise between seabird enjoyment and disturbance: the role of observed and observers. Environmental Conservation 35: 104-108.

Nelson JB. 2005. Pelicans, cormorants, and their relatives: the Pelecaniformes, 680 pp. Oxford University Press, Oxford.

Nisbet ICT. 2000. Disturbance, habituation and management of waterbird colonies. Waterbirds 23: 312-332.

Punta G, P Yorio, G Herrera \& J Saravia. 2003b. Biología reproductiva de los cormoranes Imperial (Phalacrocorax atriceps) y Cuello Negro (P. magellanicus) en el Golfo San Jorge, Chubut, Argentina. El Hornero 18: 103-111.

Punta G, P Yorio, J Saravia \& P García Borboroglu. 2003a. Breeding habitat requirements of the Imperial Cormorant and Rock Shag in central Patagonia, Argentina. Waterbirds 26: 176-183.

Raya Rey A \& ACM Schiavini. 2000. Distribution, abundance and associations of seabirds in the Beagle Channel, Tierra del Fuego, Argentina. Polar Biology 23: 338-345.

Rodgers JA \& ST Schwikert. 2002. Buffer-zone distances to protect foraging and loafing waterbirds from disturbance by personal watercraft and outboard-powered boats. Conservation Biology 16: 216-224.

Ronconi RA \& CCS Clair. 2002. Management options to reduce boat disturbance on foraging black guillemots (Cepphus grylle) in the Bay of Fundy. Biological Conservation 108: 265-271.

Rosciano NG. 2011. Factores ambientales y humanos que determinan la distribución y abundancia del Cormorán Imperial (Phalacrocorax atriceps) y el Cormorán Cuello Negro (Phalacrocorax magellanicus) en el Canal Beagle,
Tierra del Fuego. Tesis de Licenciatura, Facultad de Ciencias Exactas y Naturales, Universidad de Buenos Aires, Argentina, 46 pp.

Schiavini A \& P Yorio. 1995. Distribution and abundance of seabirds colonies in the Argentine sector of the Beagle Channel, Tierra del Fuego. Marine Ornithology 23: 39-46.

Tasker ML, PH Jones, T Dixon \& BF Blake. 1984. Counting seabirds at sea from ships: a review of methods employed and a suggestion for a standardized approach. The Auk 101: 567-577.

Velando A \& I Munilla. 2011. Disturbance to a foraging seabird by sea-based tourism: Implications for reserve management in marine protected areas. Biological Conservation 144: 1167-1174.

Villanueva C, BG Walker \& M Bertellotti. 2012. A matter of history: effects of tourism on physiology, behavior and breeding parameters in Magellanic Penguins (Spheniscus magellanicus) at two colonies in Argentina. Journal of Ornithology 153: 219-228.

Walther FR. 1969. Flight behavior and avoidance of predators in Thompson's gazelle (Gazella thompsoni: Guenther 1884). Behaviour 34: 184-221.

Whittaker D \& RL Knight. 1998. Understanding wildlife responses to humans. Wildlife Society Bulletin 26: 312-317.

Woehler EJ, RL Penney, SM Creet \& HR Burton. 1994. Impacts of human visitors on breeding success and longterm population trends in Adélie Penguins at Casey, Antarctica. Polar Biology 14: 269-274.

Yasué M. 2006. Environmental factors and spatial scale influence shorebirds' responses to human disturbance. Biological Conservation 128: 47-54.

Yorio P. 2009. Marine protected areas, spatial scales, and governance: implications for the conservation of breeding seabird. Conservation Letters 2: 171-178.

Yorio P \& PD Boersma. 1992. The effects of human disturbance on Magellanic Penguin Spheniscus magellanicus behaviour and breeding success. Bird Conservation International 2(3): 161-173

Yorio P, E Frere, P Gandini \& W Conway. 1999. Status and conservation of seabirds breeding in Argentina. Bird Conservation International 9: 299-314.

Yorio P, E Frere, P Gandini \& A Schiavini. 2001. Tourism and recreational at seabird breeding sites in Patagonia, Argentina: current concerns and future prospects. Bird Conservation International 11: 234-245.

Yorio P \& F Quintana. 1996. Efectos del disturbio humano sobre una colonia mixta de aves marinas en Patagonia. El Hornero 14: 60-66.

Zuur AF, EN Ieno, NJ Walker, AA Saveliev \& GM Smith. 2009. Mixed effects models and extensions in ecology with R, 574 pp. Springer, New York.

Received 24 October 2012 and accepted 8 March 2013

Editor: Claudia Bustos 